\title{
Portuguese Migrants in the German Labor Market: Selection and Performance ${ }^{I}$
}

Thomas Bauer

$I Z A$, Bonn and CEPR, London

Pedro T. Pereira

Universidade de Madeira

Michael Vogler

$I Z A$, Bonn

Klaus F. Zimmermann

$I Z A$, Bonn, Bonn University and DIW, Berlin

The labor market performance of Portuguese workers in Germany is analyzed in this article. While previous work has compared wages and characteristics of migrants to natives only, this study also matches the data set with an equivalent survey from the sending country. The findings show that Portuguese migrants as a whole are negatively selected, with the exception of blue-collar workers, the largest group among the movers. The finding that Portuguese migrants earn more than comparable Germans indicates that they have higher unobservable skills.

Many economic models studying the impact of immigration on the economy of a receiving country demonstrate that it is important to attract migrants with a particular endowment of skills in order to avoid negative effects on natives and to maximize the benefits of immigration. Following these arguments some immigration countries, such as Canada, the United States and Australia have established an immigration system that selects migrants according to characteristics that are beneficial to their labor markets. The German recruitment policy of the 1950s and 1960 s serves as a good example for a selection strategy that mainly follows the needs of the labor market.

However, the demand on the world market for migrants typically meets a self-selected supply. Hence, any immigration policy can only choose from

1Financial support of Acçōes Integradas Luso Alemăes (grant A 23/97 by CRUP and grant 314-AI-p-dr by DAAD), PRAXIS XXI (grant 2/2.1/CSH/781/95) and the European Commission (grant SOE2-CT97-3052) is gratefully acknowledged. We thank Rainer Winkelmann and two anonymous referees for their helpful comments. 
the pool of people willing to migrate. There is insufficient knowledge about this self-selection process, especially in Europe where most of the literature focuses on the assimilation of migrants and their impact on natives. How do migrants compare to the population in the sending and the receiving country? What does this imply for the immigration policy of the host country?

The study makes use of a large German data set (Beschäftigtenstichprobe) which was provided by the German Labor Office. The data set covers the period 1975-1990 and represents a 1 percent random sample of all employees paying social security contributions. Because of the large number of observations, it is possible to analyze the labor market performance of a relatively small group like Portuguese workers in Germany. Apart from this standard analysis of labor market performance, we analyze the selection of guestworkers in Germany in terms of observed and unobserved characteristics by combining the German data set with Portuguese cross-section data for 1982 and 1986.

The novel features of this paper are 1) the use of matched micro data from the sending and receiving regions, and 2) the study of a largely underresearched European flow of workers, i.e., Portuguese-German migration. The article first explains the institutional background and the development of migration between Portugal and Germany. A review of the theoretical background of the analysis is presented. Next, the data sets used are described and some preliminary results about the selection of Portuguese migrants are provided by comparing the characteristics of Portuguese migrants with native Germans and Portuguese nonmigrants. The results of earnings regressions are used to compare the wages of Portuguese migrants to those Portuguese who stayed at home and to similar German workers.

\section{INSTITUTIONAL BACKGROUND AND STYLIZED FACTS}

Ever since the rise of Portuguese migration to Germany in the early 1960s, the institutional setting has changed several times, causing different patterns of migration. This section provides an overview of the institutional background and the dimension and structure of migration between Portugal and Germany.

\section{The German Perspective}

Migration from Portugal to Germany was initiated by the German guestworker system. In the 1950s and early 1960s, Germany faced excess demand for unskilled blue-collar workers, which induced the establishment of an 
active recruitment policy. Recruitment treaties were signed with Italy (1955), Greece and Spain (1960), Turkey (1961), Morocco (1963), Portugal (1964), Tunisia (1965) and Yugoslavia (1968) (see Zimmermann, 1995a, for a detailed description of German immigration policy since World War II). The recruitment of Portuguese workers was dependent on several institutional bodies. German firms reported to the German Labor Office, the Bundesanstalt für Arbeitsvermittlung und Arbeitslosenversicherung, the number and the characteristics of workers they were seeking. The Bundesanstalt fiir Arbeitsvermittlung und Arbeitslosenversicherung communicated every six months the requests of German firms to the Junta da Emigração, the Portuguese counterpart to the German institution. The labor needs reported from the German institution to its Portuguese counterpart were very detailed, including a list of professional and demographic characteristics of the demanded workers as well as other types of information such as professional capabilities, type of work, duration of stay and housing conditions. If the Junta da Emigração decided to answer the German requests favorably, it selected the candidates (a detailed description of the organization and enforcement of the recruitment of guestworkers is given by Bauer and Zimmermann, 1996). By law, wage offers to guestworkers had to be identical to those for equally qualified Germans. Despite this active recruitment by the German Labor Office, there was also the possibility of the so-called "second way" of immigration to Germany. Foreign employment seekers were allowed to apply directly for jobs at the German embassy in their home country.

Facing increasing social tensions and fears during a recession after the first oil price shock, Germany stopped active recruitment of guestworkers in November 1973. This recruitment stop, however, did not imply an overall immigration halt. Due to family reunification, relatives of foreign workers in Germany were still allowed to migrate to Germany. Furthermore, citizens of European Union member states were not affected by the recruitment halt because of regulations that guaranteed the free movement of workers between the member states. However, although Portugal joined the European Union (EU) in 1986, there were mobility restrictions for Portuguese workers for a period of seven years. During this period, they were not treated as EU workers, but like third-country nationals. This regulation was introduced due to the large economic differences and the resulting fear of mass migration to the core of the EU.

Figure I summarizes the migration flows from Portugal to Germany from 1960 to 1995 . In response to the German excess demand for unskilled 
labor and the beginning of active recruitment in Portugal (1964), the flow of Portuguese migrants grew steadily from 1960 to 1973 when recruitment was stopped. In this period, 1967 was the only year with a negative immigration balance caused by a recession in Germany. Figure II shows that the total number of Portuguese in Germany increased from close to zero in 1960 to about 120,000 in 1974 . Furthermore, until the early 1970 s, these Portuguese mainly consisted of workers.

Figure I.

\section{Migration of Portuguese to Germany}

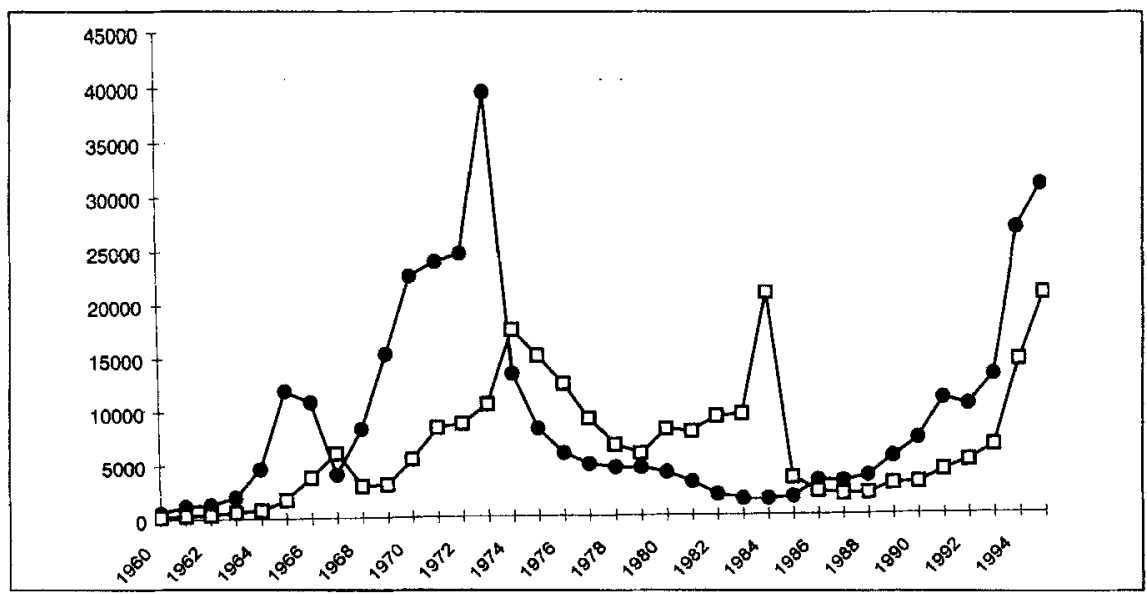

Source: Statistisches Bundesamt (various years)

Figure II.

Size of Portuguese Population and Workers in Germany

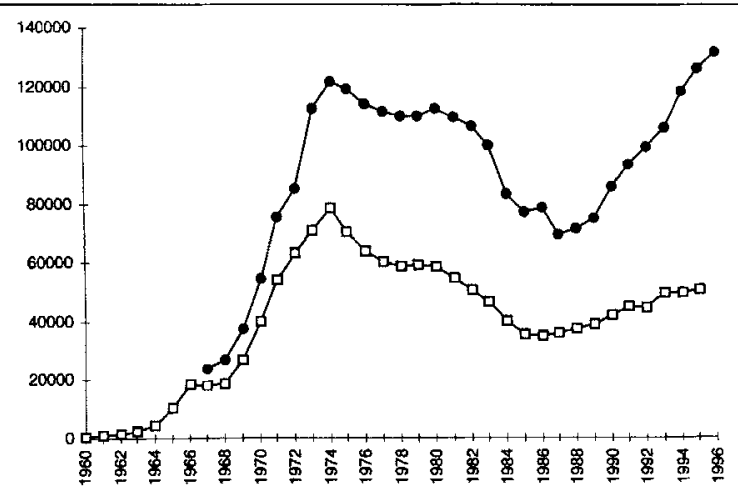

$\rightarrow$ Population $\rightarrow 0-$ Enployees

Note: The number of employees includes only workers that have to pay contributions to social security. Source: Statistisches Bundesamt (various years); Bundesanstalt für Arbeit (various years) 
After the recruitment stop, the migration balance remained negative until 1986. Return migration reached a peak in 1983 (see Figure I) when the German government established a return program that could be claimed by workers who became unemployed or were working shorter hours for a longer period. Figure II shows that the total number of Portuguese employees decreased by 54 percent from its peak in 1974 until 1987, whereas the overall Portuguese population only decreased by 43 percent (from 122,000 to $69,000)$. These numbers indicate increasing migration through family reunification after the recruitment stop.

Since 1986, when Portugal joined the European Union, Germany again experienced a positive net immigration from Portugal, which increased sharply in 1993 when free mobility for Portuguese workers started. From 1992 to 1995 , the Portuguese population increased by about 27,000 persons, but the number of Portuguese employees increased only by 5,000. An explanation for this may be the growing number of so-called Werkvertragsarbeiter from Portugal working in Germany, especially on building sites. Werkvertragsarbeiter are persons who work in Germany, but are formally employed by Portuguese companies; they do not pay contributions to the German social security system and are not listed in the official labor statistics of Germany (see Bauer and Zimmermann, 1996, 1997, for a more detailed description of the legal constraints to immigrate as Werkvertragsarbeiter). Hence, only limited information about the number and origin of these workers in Germany is available. Estimates of the overall number of Werkvertragsarbeitnehmer range from 150,000 to 200,000 - mainly from the United Kingdom, Ireland and Portugal. Because these workers are paid much less than their German counterparts, this has created immense public tensions due to the perceived cause of rising native unemployment, especially in the construction sector. In early 1996, the German government reacted to these tensions by passing a law (Entsendegesetz) to force foreign companies to pay German wages for Werkvertragsarbeiter.

Finally, it is worth noting that Portuguese workers are only a minor group among all foreign employees in Germany. After the stop of recruitment in 1974, their fraction of all foreign guestworkers was about 3.4 percent and decreased to about 2.4 percent in 1996.

\section{The Portuguese Perspective}

Portugal has a long history of emigration, with the overseas territories being the main destination in the last centuries. Freedom of mobility, however, was 
a right denied to the Portuguese during most of the twentieth century. Article 31 of the Constitution of 1933 stated: "The State has the right ... 5) [to] protect the emigrants and control emigration." According to law 33918 of 1944 , article 17, "It is forbidden to issue ordinary passports to workers of any industry or rural workers" (quoted in Ribeiro, 1986:2). Illegal emigration, i.e., leaving the country without an emigration passport, was a crime punishable by law. Freedom of mobility was an achievement of the Democratic Revolution in 1974.

In 1947 the Junta de Emigração was created with the aim of determining the number of emigrants allowed to migrate to each country and the number of workers allowed to migrate for each region and each profession. Under this legal "umbrella," the majority of Portuguese emigrants headed towards Brazil (237,000 out of 350,000) in the decade 1950-1959. Europe did not attract many emigrants in this period: it was the destination for less than 7 percent of all Portuguese migrants; less than 1 percent of these emigrants chose Germany as their destination (93\% chose France).

A change became visible in the 1960s. First, the law was revised in 1962 (Laws 44427 and 44428) to meet the economic needs of the country. Following this change, bilateral agreements were signed with Holland and France in 1963 and Germany in 1964. At that time it was impossible to restrict migration to 30,000 persons per year, which had been announced by the authorities as the desired level of emigration (Ribeiro, 1986). As a result of the bilateral agreements, emigration between 1960 and 1969 increased to more than 797,000, with Europe being the main destination region. Almost 70 percent of all Portuguese emigrants chose a European destination country, with Germany attracting more than 10 percent (France 86\%). Brazil experienced a large decrease in immigration (to 73,267) from Portugal. In the 1970 s, emigration further increased slightly to more than 850,000 . During this period, more than 77 percent of the Portuguese emigrants went to a European country; Germany received about 23 percent of all Portuguese emigrants in this time period, France received 57 percent. Brazil accounted for less than 2 percent of the emigrants.

Looking at Portuguese emigration since the 1950s, in particular in the period from the mid 1960 s to mid the 1970 s, one can observe a large difference between legal emigration as defined by the Portuguese law and total emigration (see, e.g., Baghana, 1991, 1993, 1994; Pereira, 1993). In 1970, more than 100,000 Portuguese emigrated illegally, which is almost double the number of legal migrants. France received by far the greatest number of legal 
migrants and was also the destination of a large number of illegal migrants (Ribeiro, 1986). Baganha and Góis (1999) stated that legal emigration to Germany underestimated the real flow by 27 percent in the period from 1962 to 1969 and by 42 percent in the period from 1972 to 1979 (the respective numbers for France are $41 \%$ and $81 \%$ ).

The role of the Junta de Emigração in selecting migrants is stated in the Portuguese-German agreement. The Junta de Emigração would present a list of candidates it deemed appropriate to take into consideration for the requests of German firms. Even in the case of firms that asked for a particular worker, the Junta had to authorize migration following its own rules. According to these rules, some professions were banned for migration, and potential migrants had to change their professions if they wanted to be successful in their applications. In some cases, people invented and proved four or five different professions trying to get a permit, but never received one (Ribeiro, 1986:42).

One might argue that mainly political reasons could explain the large emigration flows from Portugal in the 1950s and 1960s. During this period, war in the overseas territories began (1961), and the draft increased by more than 100,000 persons per year at its peak. Political reasons to migrate as a way to avoid the draft or to oppose the dictatorial regime, however, do not seem to explain the vast majority of emigration. As Serra (1985) shows, most emigrants aimed to increase their standard of living, and almost 60 percent migrated to countries they had chosen freely. Economic motives seemed predominant for most of the Portuguese migration.

The importance of the economic component of the migration decision is further confirmed by the analysis of Pereira (1994). He shows that Portuguese emigration in the period from 1958 to 1985 is positively related to wages in the receiving countries and negatively related to wages in Portugal. Both effects, however, are not symmetric, meaning that it is not only their difference that matters but also their level. A similar argument was put forward by Murteira (1965), who stated that the fact that wages paid in Portugal were not sufficient to sustain a certain standard of living can better explain emigration than wage differentials. Pereira (1994) also shows that Portuguese migration is positively related to wealth, revealing the existence of imperfect capital markets. In sum, Pereira's (1994) analysis shows that the high wage gap between Portugal and the receiving countries is the main driving force behind Portuguese emigration.

Baganha (1994) shows that the Portuguese development process was constrained by the low number of high-qualified workers (liberal professions, 
scientists, etc.). As there is no evidence of emigration of these types of workers, people who emigrated can be viewed as a surplus in the internal labor market. Following this argument, Portugal was "selling a good" for which it had no use. Hence there was no loss to Portugal from emigration - independent of the value it received for it (Baganha, 1994). In this context, the importance of remittances should be stressed. In 1970, remittances covered 30 percent of imports and 139 percent of the import of equipment goods. In this year, exports were 24.6 percent of GNP - not enough to cover the costs of imports (30.6\% of GNP). Hence, migrants helped to finance the necessary imports for goods.

\section{THE THEORETICAL BACKGROUND}

The economic literature on migration (for recent surveys, see Borjas, 1994; Zimmermann, 1995a) can be separated into two broad categories. Within the first category, the effects of migration on the receiving country have been analyzed. This line of research has focused mainly on the following questions. How do migrants perform in the economy of the receiving country? What are the consequences of immigration for native labor? Which kind of immigration policy maximizes the host countries' benefits from immigration? The second category takes the view of the sending country and analyzes the effects of the brain drain, the nature and effects of return migration, and the effects of remittances.

Both areas are closely related. For example, if the receiving country is able to attract immigrants with high levels of productivity who adapt rapidly to the host country's labor market, migration can make a significant contribution to economic growth. On the other hand, the loss of highly productive workers may have an adverse effect on the economic growth of the sending countries. Using data from the sending and receiving countries, we combine the two strands of migration literature by comparing the characteristics and wages of Portuguese guestworkers in Germany to workers who decided to stay in Portugal as well as to native German workers.

\section{The Importance of Attracting the "Right" Immigrants}

Economic theory predicts quite different results regarding the effects of immigration on the labor market, depending upon the particular structure of the model used. Assuming homogeneous labor, the standard competitive framework suggests that immigration has a negative effect on wage rates and 
a positive effect on the productivity of capital in the receiving country, with the reverse happening in the sending country. In total, immigration results in an increase of total welfare at the expense of labor in the receiving country and the expense of capital in the sending region. This kind of model seems to be adequate for the German situation in the 1950s and early 1960s (see Bauer and Zimmermann, 1997, 1998, for a more detailed discussion). It is widely accepted that the level of economic prosperity that West Germany obtained in those decades would have been difficult to reach without the contributions of foreign workers. By its very nature, this form of immigration from Portugal and the other sending countries should have been the most profitable for the German economy, since the recruitment of guestworkers was oriented as much as possible to the particular demands of German firms.

However, there is no reason to believe that such an equilibrium situation would prevail after the first oil price shock in 1973 . The general theoretical framework provided by Schmidt, Stilz and Zimmermann (1994) can be used as a point of departure to study the labor market effects of immigration under a disequilibrium situation. In a model with heterogeneous labor, the authors allow for the possibility that wages may not be downwardly flexible due to the behavior of unions, causing unemployment of unskilled workers. These imperfections are crucial in the analysis of migration after the recruitment stop in 1973. If union behavior remains unaffected by immigration, new immigrants may cause unemployment to rise. However, unions' wage-employment choice may be affected by the pressure of increased unemployment or by the possibility of giving different weights to the interests of different groups of workers.

If labor is indeed heterogeneous, the key issue for the evaluation of the effects of immigration is whether foreigners are substitutes or complements to natives. Assume there are only two types of labor, skilled and unskilled, where skilled and unskilled workers are complements. Immigrants are considered to be substitutes for unskilled natives and complements to skilled natives. Hence, increased immigration may depress wages and (possibly) increase unemployment of unskilled native workers and may induce the reverse effects for the skilled. Within a framework that allows for the possibility of unemployment in the host country, immigration of skilled and unskilled workers can be shown to be beneficial, if wages of unskilled workers will be (by weakening the position of the unions) somewhat downwardly flexible, and the economy comes closer to a competitive framework. Native unemployment may also fall. However, the losses for the economy can also be 
quite substantial if new labor moves into those market segments that exhibit unemployment and unions are inflexible (see Zimmermann, 1996b, for a particular example and Bauer and Zimmermann, 1996, 1997, 1998, for a calibration of the model using German and European data).

The arguments above suggest that it is important for the host country to attract migrants with a particular endowment of skills in order to avoid negative effects of immigration on the economy and to maximize the benefits of immigration. In the period of active recruitment of foreigners, Germany demanded mostly unskilled blue-collar workers for which there was an excess demand in the labor market. The demand of a receiving country for a particular type of foreign worker, however, faces a self-selected supply. The Roy model is a popular model in the migration literature to analyze the selfselection of migrants. A formal representation of this model for the explanation of international migration flows can be found in Borjas $(1987,1994)$.

\section{Self-selection of Migrants}

According to the Roy model, immigrants can be either positively or negatively self-selected with regard to observed as well as unobserved characteristics, depending on the relative value of their characteristics in the sending and receiving countries. For example, positive selection in the schooling level (i.e., the mean schooling level of migrants is greater than the mean schooling level of the population of the country of origin) occurs when the labor market in the host country attaches a higher value to schooling than does the sending country. Conversely, high-skilled individuals have little incentive to migrate if the rate of return to schooling in the host country is lower compared to the country of origin. Negative self-selection in terms of unobserved characteristics, such as motivation, occurs if the wage distribution in the receiving country is less dispersed than in the sending country. In this case, highly qualified workers are in a sense taxed whereas low-ability workers are insured against poor labor market outcomes. In either case, the decision of a person to migrate leads to a self-selected pool of migrants, and every migration policy is only able to select individuals out of this self-selected pool.

The description of the institutional setting of the recruitment of Portuguese guestworkers as described above shows that the selection process of Portuguese migrants has mainly been influenced by two different governmental agencies, the Bundesanstalt für Arbeitsvermittlung und Arbeitslosenversicherung on the German side and the Junta da Emigração on the Portuguese side. Governmental interventions make the selection process more compli- 
cated. This does not, however, change the fundamental propositions of the Roy model. In the case of the migration of Portuguese guestworkers to Germany, the Bundesanstalt für Arbeitsvermittlung und Arbeitslosenversicherung can be thought of as the demand side of the migration market, which defines the characteristics of the migrants it wants to accept. On the supply side of the migration market there is the pool of potential migrants which self-selects itself following the Roy model. The Junta da Emigração is the institution that matches supply and demand. As long as the Junta da Emigração decides to follow the requests of the German Labor Office, it could select the candidates only from the self-selected pool of potential migrants. It can be expected, however, that the Junta da Emigração decides not to answer the request of the German institution favorably if it expects a disadvantage for the Portuguese labor market. In the case where it answers the German requests favorably, it could be expected that the Junta da Emigração selects the least qualified workers out of the pool of potential migrants; unfortunately there is no data to test this assertion.

The following sections combine German with Portuguese data to identify the pattern of self-selection of Portuguese migrants in terms of education and unobserved characteristics. A first step is to compare the characteristics of Portuguese workers in Germany with those of Germans and of Portuguese who stayed in their home country. Second, we use earnings regressions to identify the direction of the self-selection of Portuguese guestworkers by comparing the potential earnings of Portuguese migrants in their home country with those they actually receive in Germany as well as comparing the actual earnings of Portuguese workers who stayed at home with the amount they would have earned in Germany.

\section{DATA SET AND ECONOMETRIC METHOD}

\section{Data Set}

Although the performance of guestworkers in the German labor market has been the subject of several empirical studies, there is hardly any evidence on Portuguese workers. This can mainly be attributed to the lack of appropriate data. Portuguese workers are only a small fraction of the German labor market (even among foreign workers) and hence were not sufficiently sampled in previous surveys with smaller sample sizes, such as the German Socioeconomic Panel. The data situation changed in 1996, when the German Labor Office provided access to the 1975-1990 files of the Beschäftigtenstichprobe (Employment Statistic Register Sample). 
The Beschäftigtenstichprobe of the German Labor Office is a 1 percent sample of all workers in Germany who pay social security contributions, excluding self-employed people, public servants and those with insignificant work. It covers the period from January 1, 1975 to December 31, 1990 (for some restrictions of the survey, see Bender et al., 1996; Bender, Haas and Klose, 2000). For the purpose of this study, we constructed four cross-sections at March 1 of the years 1975, 1982, 1986 and 1990. The data set, however, has some major drawbacks. First, there is no way to determine the number of years since migration of foreign workers. Second, wages are censored from above. This is due to the fact that there is an upper limit to which social contributions have to be paid proportionally to the wage. Third, the data set provides no information on hours worked. To mitigate this problem, we will restrict our analysis to full-time employed males.

We drew random subsamples of all available male Germans after excluding individuals with incomplete observations for the years 1975, 1982, 1986 and 1990 , resulting in about 60,000 observations for each year. Furthermore, we included all male Portuguese in Germany that were present in the labor survey on March 1, respectively. Because of the relatively small number of Portuguese workers and due to the exclusion of individuals with incomplete observations, the resulting sample sizes are still small, ranging from 380 Portuguese migrants in 1975 to 183 in 1986.

For the years 1982 and 1986, we were able to merge a Portuguese data set with the German data. The Portuguese data was drawn from Quadros de Pessoal (Employees Records) of the Portuguese Ministry for Employment and Social Security (see Vieira, 1999, for a more complete description of the data set). All firms with wage earners must fill in a standardized questionnaire. The data does not include public servants, but it contains information for more than 2 million workers on profession, qualification, education, tenure, age, sex, base-wage, regular allowances, irregular allowances and working hours. It covers more than 150,000 firms with information on their location, type of firm and ownership. The firms have provided the data since 1982 on an annual basis. The survey is cross-sectional, but it is possible to create panel data on firms and workers. From this main data set a random subsample has been made available for research. After excluding observations with missing values on one of the used variables, 41,673 and 39,437 individuals remained for the empirical analysis of the Portuguese data set for the years 1982 and 1986, respectively.

Due to some differences in the definition and construction of the variables in both data sets, some adjustments were necessary. Table 1 provides a 
description of the final data set and the respective definitions of the used variables. Table 2 contains descriptive statistics of the 1975 and 1990 German samples, as well as for the years 1982 and 1986, for which we were able to match the Portuguese data. As expected, Portuguese workers in Germany have a lower level of education than natives. In 1975, 76.8 percent of Portuguese workers in Germany had less than thirteen years of schooling with no additional formal vocational training (Germans: $21.6 \%) .{ }^{2}$ In the following years, this percentage continuously decreased to 69.2 percent in 1990 (Germans: $15.2 \%$ ). In the whole period 1975-1990, there were no Portuguese workers with a bachelor's or university degree in Germany. Compared to the Portuguese workers in Portugal, two points are remarkable. First, significantly more Portuguese workers in Germany had formal vocational training (1982: $24.1 \%$ compared to $7.4 \%$ ). Second, there are persons with a bachelor's or university degree among Portuguese workers who stayed in Portugal. These results indicate a negative selection regarding educational attainment but a positive selection of workers with low school education but vocational training. Furthermore, in 1975 most Portuguese workers in Germany (76.1\%; Germans $21.5 \%)$ were working in unskilled blue-collar jobs and very few in white-collar jobs (0.5\%; Germans 33.0\%). Until 1990, however, the differences in the occupational distributions of Portuguese workers in Germany and Germans became smaller.

Investigating the sectoral distribution, Table 2 shows that in 1975 Portuguese workers in Germany were mainly employed in the Mechanical Engineering (18.2\%; Germans 16.6\%), Textile (15.3\%; Germans 2.3\%) and Iron (12.4\%; Germans $6.6 \%$ ) sectors. While the shares of the sectors Mechanical Engineering and Iron stayed relatively constant, the sectors Textile $(15.3 \%$ to $7.1 \%)$, Chemistry $(9.5 \%$ to $6.6 \%)$ and Mineral and Metallic (7.4\% to $4.3 \%)$ lost some of their importance. The number of Portuguese workers in Germany working in the different service sectors increased from 11.1 percent in 1975 to 21.8 percent in 1990 .

2Note that we define vocational training as formal vocational training as it is defined in the German context. In Portugal, the six-year compulsory education started in 1964. According to the 1986 cross-section of the Portuguese data, the majority of individuals entering the first year of education after 1963 hold at most four years of education $(53.5 \%)$ and the average education is 6.52 years (see Vieira, 1999). In 1997, the population in the age between 25 and 59 that had finished at least secondary education was $82.1 \%$ in Germany and $23.8 \%$ in Portugal. These numbers may explain the comparably low number of Portuguese workers in Germany without formal vocational training. 
TABLE 1

The Data SeT

\begin{tabular}{|c|c|}
\hline \multicolumn{2}{|c|}{$\begin{array}{l}\text { Germans in Germany: } 1975-1990 \text { (ca. 40,000-45,000 per year) } \\
\text { Portuguese in Germany: } 1975-1990 \text { (maximum 380 (1975); minimum } 183 \text { (1986)) } \\
\text { Portuguese in Portugal: } 1982(42,000), 1986(40,000)\end{array}$} \\
\hline Variables: & Sectors: \\
\hline Gross monthly wage & $\begin{array}{l}\text { Mining } \\
\text { Food, tobacco }\end{array}$ \\
\hline Low school education (Germany: <13 years (Abitur); Portugal: & Texcile \\
\hline$<11$ years) & Wood \\
\hline High school education & Paper \\
\hline (Germany: 13 years; Portugal $11-12$ years) & Chemistry \\
\hline Vocational training & Minerals, no metallics \\
\hline Bachelor's degree (Germany: Fachhochschule) & Iron, sreel \\
\hline University degree & $\begin{array}{l}\text { Mechanical engineering } \\
\text { Other machines }\end{array}$ \\
\hline Age & Energy \\
\hline $\mathrm{Age}^{2}$ & $\begin{array}{l}\text { Construction } \\
\text { Trade }\end{array}$ \\
\hline Blue collar 1 (no qualification) & Hotel \\
\hline Blue collar 2 (small qualification) & Transport, communication \\
\hline Blue collar 3 (high qualification) & Banks, insurance \\
\hline White collar & $\begin{array}{l}\text { Cleaning } \\
\text { Other services }\end{array}$ \\
\hline $\begin{array}{l}\text { Firm size } 1 \text { ( } 1-10 \text { employees) } \\
\text { Firm size } 2 \text { (10-100 employees) } \\
\text { Firm size } 3 \text { ( } 100-500 \text { employees) } \\
\text { Firm size } 4 \text { ( } 500-1000 \text { employees) } \\
\text { Firm size } 5 \text { ( }>1000 \text { employees) }\end{array}$ & \\
\hline
\end{tabular}

A question that arises at this point of the analysis is whether the sectoral distribution of Portuguese workers in Germany is similar to the sectoral distribution in Portugal and whether the sectoral distribution of Portuguese workers in Germany adjusts over time to that of German workers. Table 3 contains simple correlation coefficients that provide some interesting insights. It shows that the sectoral distribution of Portuguese workers in Germany was always more similar to the Germans than to the Portuguese who stayed in Portugal. This similarity might be the result of the recruitment process we described earlier since the demand for Portuguese guestworkers was mainly driven by the needs of the German economy and should therefore show a higher correlation with the German employment distribution if compared to the Portuguese distribution. In addition, between 1975 and 1990, Portuguese workers in Germany steadily assimilated to the German distribution. The changes within the group of Portuguese workers in Germany between 1975 and 1990 were obviously greater than those among Germans. 


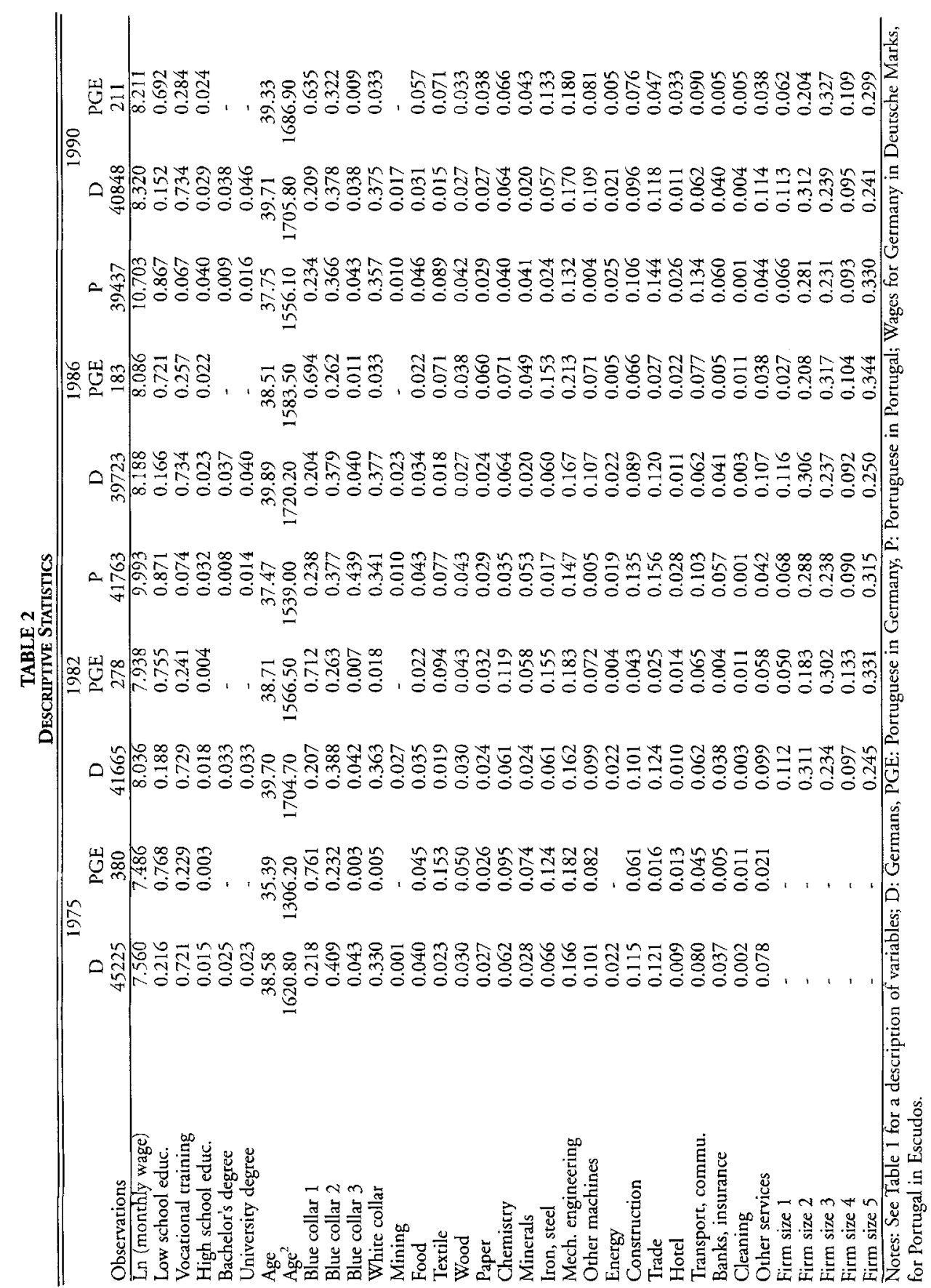


TABLE 3

CORRELATION COEFFICIENTS OF THE SECTORAL. DisTRIBUTION OF WORKERS

\begin{tabular}{lccccc}
\hline & 1975 & 1982 & 1986 & 1990 & $1975-1990$ \\
\hline D-PGE & 0.48 & 0.54 & 0.61 & 0.66 & \\
D-P & & 0.67 & 0.57 & & \\
PGE-P & & 0.27 & 0.38 & & 0.97 \\
D-D & & & & 0.92 \\
PGE-PGE & & & \\
\hline Note: D: Germans; PGE: Porruguese in Germany; P: Portuguese in Portugal &
\end{tabular}

Compared to natives, Portuguese workers in Germany show a higher concentration in larger companies. While in 1977 - the year for which the first information on firm size is available -17.3 percent were employed in firms with less than 100 employees, this share increased to 26.6 percent in 1990 (Germans $42.5 \%$ ). Furthermore, in 1975, Portuguese workers in Germany were on average three years younger than Germans. Even in this respect they became more similar to the natives. Over the whole period, Portuguese workers in Germany became only four years older than Germans, which indicates that we are not able to control for people who immigrated after 1975 or returned home or to correctly measure second-generation migrants. However, in the 1990 sample, there are only seven workers who were born after 1970 . Because family reunification became important after 1973, it can be assumed that nearly all workers in the sample were born in Portugal. But the number of workers that received at least a share of their education in Germany might be larger. However, because they were born before 1954, at least 126 of the 210 workers in the 1990 sample should have received their full education in Portugal.

\section{Econometric Method}

In order to compare how Portuguese guestworkers are doing in comparison to their German counterparts, we estimate standard Mincer-type earnings functions (Mincer, 1974) of the form

$$
\ln w_{i j}=X_{i j}^{\prime} \beta_{j}+\varepsilon_{i j}
$$

where $\ln w_{i j}$ refers to the logarithm of $\log$ daily wages for individual $i$ in group $j, X_{i j}$ is a vector of explanatory variables, $\beta$, refers to the coefficients to be estimated and $\varepsilon_{i j}$ is an error term that is normally distributed with mean 0 and variance $\sigma^{2}$. Equation (1) is estimated separately for Portuguese migrants in Germany and native Germans for the years 1975, 1982, 1986 and 1990 and for Portuguese workers in Portugal for the years 1982 and 1986. Since the wage is censored from above in the German data, equation (1) is estimated using the Tobit regression model (see Greene, 1997). For the Portuguese data, 
equation (1) is estimated using OLS.

Using the results of the estimated earnings equations, we perform a standard decomposition analysis (Oaxaca, 1974). This decomposition separates the wage differential between two groups of individuals into two components: i) the wage differential due to differences in skill endowments, and ii) an unexplained part which is due to differences in the remunerations of those characteristics. The latter are used to draw some conclusions on the selfselection of migrants with regard to unobserved characteristics relative to the native population. The predicted wage differential between Portuguese workers in Germany (PGE) and Germans (D) can be calculated as

$$
\overline{\ln w_{P G E}}-\overline{\ln w_{D}}=\beta_{P G E} \overline{X_{P G E}}-\beta_{D} \overline{X_{D}}
$$

where $\beta_{j}, \mathrm{j}=\mathrm{PGE}, \mathrm{D}$, are the estimated coefficients and $\bar{X}_{j}$ are the means of the characteristics of Portuguese workers in Germany and native Germans, respectively. Subtracting and adding $\beta_{D} \bar{X}_{P G E}$ from this difference and changing the order results in

$$
\overline{\ln w_{P G E}}-\overline{\ln w_{D}}=\left(\beta_{P G E}-\beta_{D}\right) \overline{X_{P G E}}+\beta_{D}\left(\overline{X_{P G E}}-\overline{X_{D}}\right)
$$

The first term on the right-hand side is the unexplained part of the wage differential between Portuguese and German workers. The second term is the component of the wage differential, which is due to differences in the mean characteristics of the two types of workers. The unexplained part is equivalent to the difference in the actual wage and the predicted wage, the latter calculated by using German coefficients for the Portuguese sample. The unexplained part of the wage differential is usually interpreted as a measure of discrimination. Since, in Germany, workers with the same characteristics must, in principle, be paid the same wages, we interpret this unexplained part of the percentage wage differential as a measure of the differences in unobserved skills between natives and Portuguese migrants.

A consequence of the censoring of the dependent variable in the German data is that one cannot calculate the sample means of $\overline{\ln w_{j}}$ using equation (1). Instead, one has to use the predicted values of $\overline{\ln w_{j}}$ conditional on the means of the explanatory variables:

$\ln \hat{w}_{P G E}-\ln \hat{w_{D}}=\left[\ln \hat{w}\left(\overline{X_{P G E}}, \beta_{P G E}\right)-\ln w\left(\overline{X_{P G F}}, \beta_{D}\right)\right]+$ $\left[\ln w\left(\bar{X}_{P G E}, \beta_{D}\right)-\ln w\left(\overline{X_{D}}, \beta_{D}\right)\right]$ 
The estimated Tobit-estimators for $\beta_{P G E}$ and $\beta_{D}$ are used in the following section to decompose the wage differential between Portuguese workers in Germany and native German workers according to equation (4).

\section{WAGE EQUATIONS AND AN ANALYSIS OF SELF-SELECTION}

Table 4 shows the estimation results for equation (1). As can be seen from Table 4, the coefficients for education of the Portuguese workers in Germany are hardly significant and unstable in signs. Vocational training as well as a higher school degree had no effect on the wage in Germany. Incomparability of education and training, country-specific human capital or imperfect abilities to transfer human capital may be an explanation for this finding. As has been noted, relatively many Portuguese with vocational training came to Germany, but nobody with a bachelor's or university degree. One possible explanation can be traced by the wage equations. Although the returns to educational degrees are higher for each educational group in Portugal if compared to Germany, the differences are largest for bachelor's and university degrees. Therefore, highly educated persons in Portugal should have had the smallest incentives to migrate to Germany.

Similar to the education variables, the returns to occupational status are more dispersed in Portugal than in Germany. Furthermore, the coefficients for occupational status are very similar for Portuguese workers in Germany and Germans. Looking at the three sectors in which Portuguese workers in Germany are traditionally concentrated, we see that the Textile sector is a very lowpaid sector in Portugal as well as in Germany. Both the Mechanical Engineering and Iron sectors are poorly paid in Portugal but well-paid in Germany.

Using the estimation results in Table 4, we calculated the predicted wage differential between Portuguese nonmigrants, assuming that they would have been working in Germany and Portuguese workers in Germany, i.e., $\ln w\left(\overline{X_{p}}, \beta_{P G E}\right)-\ln w\left(\overline{X_{P G E}}, \beta_{P G E}\right)$, and the wage differential between Portuguese emigrants assuming that they would have stayed in Portugal and Portuguese nonmigrants, i.e., $\ln w\left(\overline{X_{P G E}}, \beta_{p}\right)-\ln w\left(\overline{X_{p}}, \beta_{p}\right)$. Table 5 demonstrates that Portuguese workers who stayed in Portugal would have received higher wages in Germany than would have emigrants $(1982:+3.1 \% ; 1986:+5.5 \%)$. This result raises the question of why workers with higher earnings potential in Germany stayed in Portugal. As shown above, the remuneration of education in Portugal is much higher than in Germany. Apparently, this higher remuneration outweighs the higher earnings potential in Germany. On the other hand, Table 5 shows that emigrants would have had lower wages in Portugal than nonmigrants $(1982:-6.6 \% ; 1986:-5.8 \%)$ have received. 


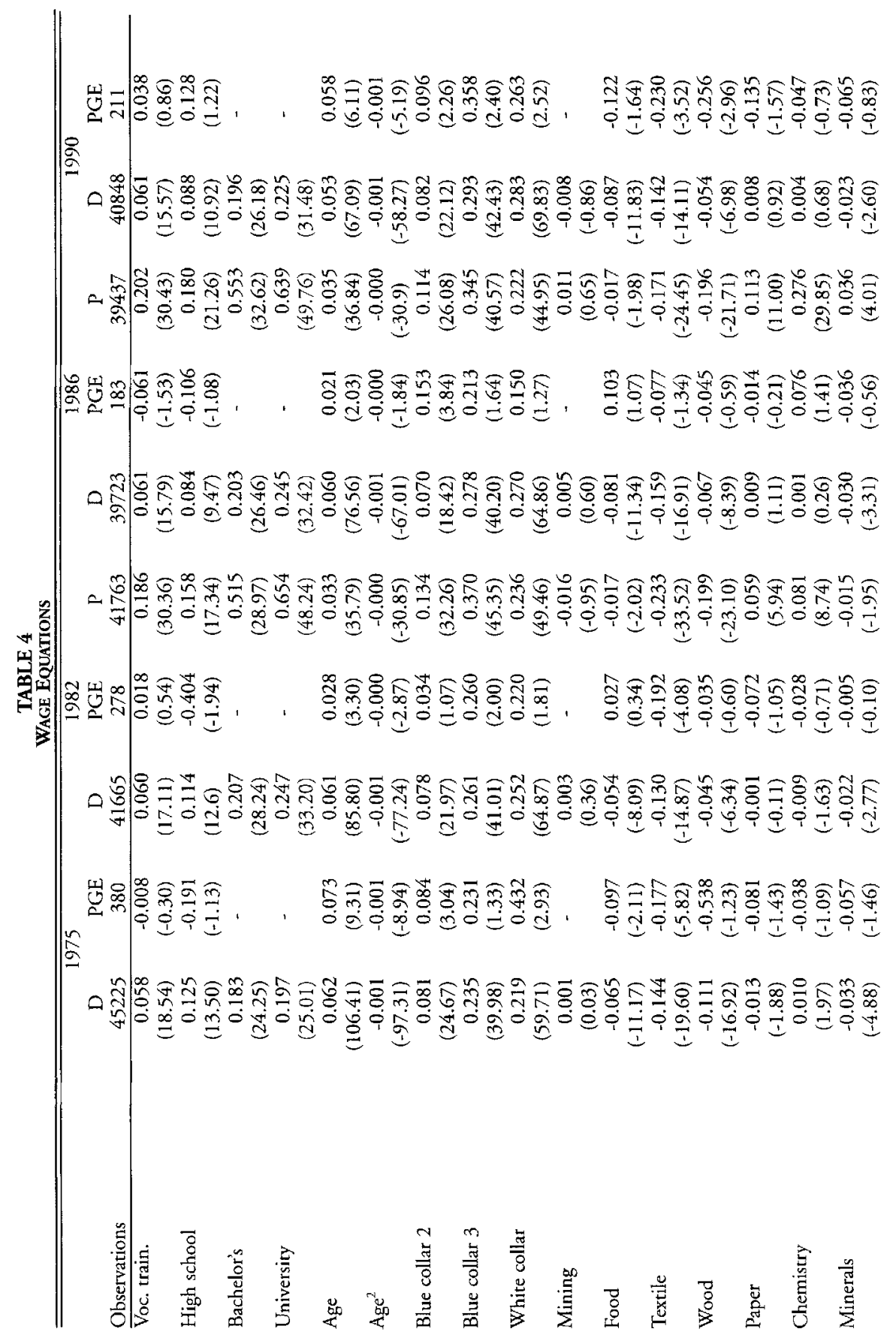




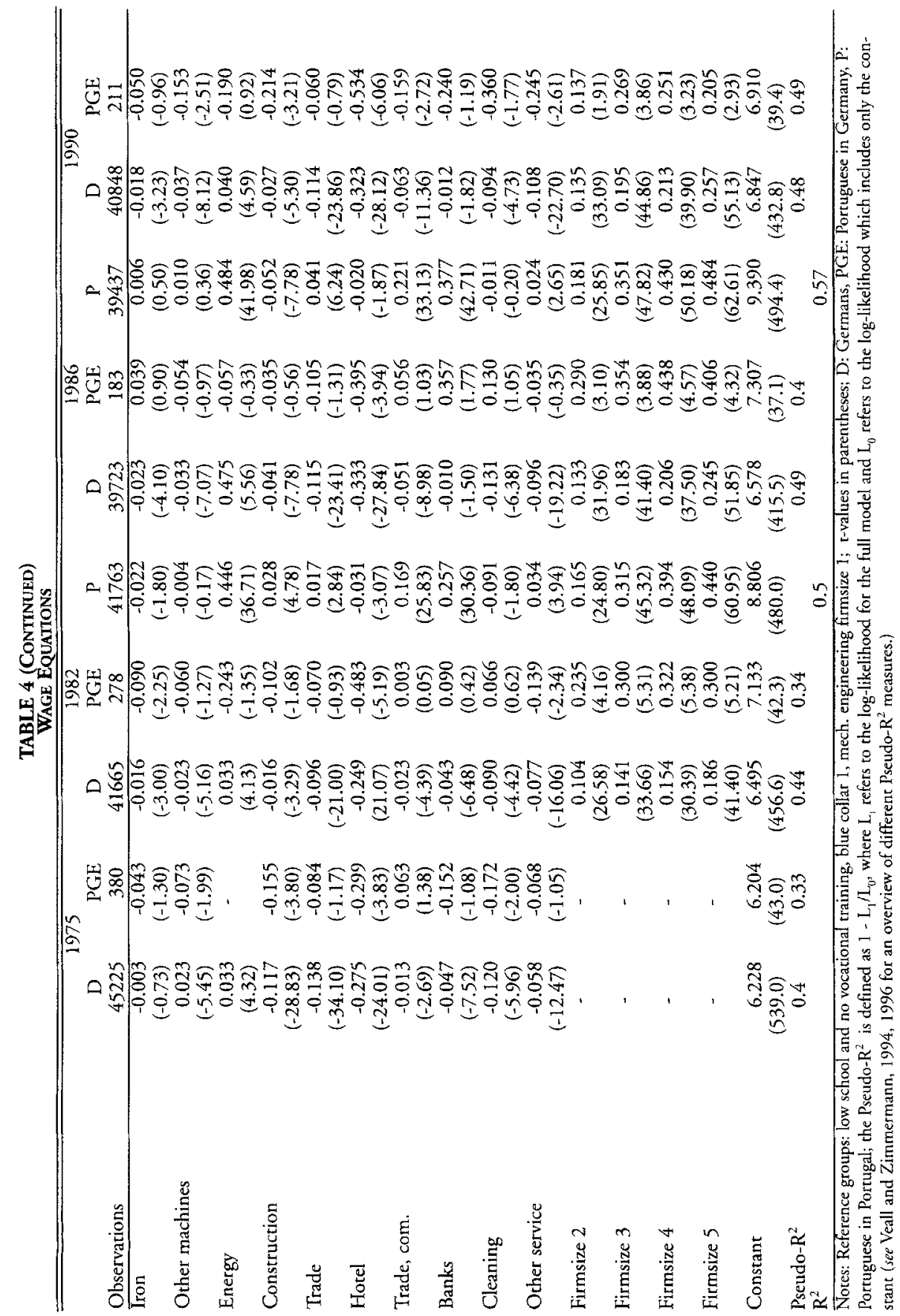


TABLE 5

Predicted Wage Differential Between Portuguese Migrants and Non-Migrants

\begin{tabular}{|c|c|c|c|c|}
\hline & \multicolumn{2}{|c|}{1982} & \multicolumn{2}{|c|}{1986} \\
\hline & (1) & (2) & (3) & (4) \\
\hline & (DM) & (PTE) & $(\mathrm{DM})$ & (PTE) \\
\hline All & 0.031 & -0.066 & 0.055 & -0.058 \\
\hline \multicolumn{5}{|l|}{ Subgroups: } \\
\hline Low school, no voc. training & 0.026 & -0.063 & 0.043 & -0.051 \\
\hline Vocational training & 0.168 & -0.216 & 0.119 & -0.268 \\
\hline Age $<35$ & 0.030 & -0.065 & 0.054 & -0.037 \\
\hline Age 35-49 & 0.088 & -0.140 & 0.090 & -0.126 \\
\hline Age $>50$ & 0.057 & -0.117 & 0.081 & -0.111 \\
\hline Blue collar 1 & -0.103 & 0.134 & -0.092 & 0.156 \\
\hline Textile & 0.009 & 0.035 & 0.022 & 0.016 \\
\hline Iron & 0.043 & -0.130 & 0.103 & -0.155 \\
\hline Mechanical engineering & 0.042 & -0.010 & 0.055 & 0.031 \\
\hline Chemistry & 0.087 & -0.185 & 0.095 & -0.157 \\
\hline \multicolumn{5}{|c|}{ 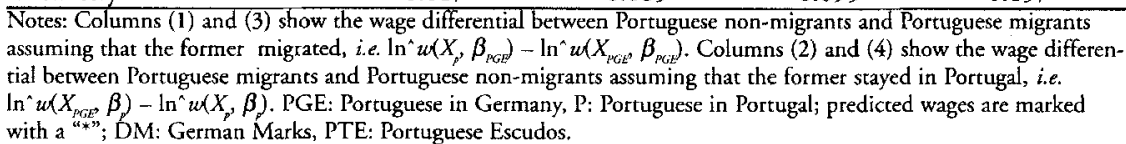 } \\
\hline
\end{tabular}

The above pattern is valid for most of the subgroups that were analyzed. Workers who migrated to Germany would have earned less in Portugal than their counterparts who stayed in the home country. There is only one striking exception. If blue-collar emigrants had stayed in Portugal, they clearly would have earned more than nonmigrants $(1982:+13.4 \% ; 1986:+15.6 \%)$. On the other hand, blue-collar workers who stayed in Portugal would have earned less in Germany than the workers who actually did migrate (1982: $-10.3 \% ; 1986:-9.2 \%)$. This is a clear indication that, while there was a negative selection of migrants within the pool of the whole Portuguese labor force, the group of blue-collar migrants seems to be positively selected. As the discussion has shown, low-skilled blue-collar workers represent the majority of Portuguese workers in Germany and about 70 percent of our sample of Portuguese workers in Germany (see Table 2).

Table 6 shows the calculated wage differentials between Portuguese workers in Germany and native Germans, as well as the (Oaxaca) decomposition of this differential into the unexplained and explained parts for the years 1975, 1982, 1986 and 1990. It appears that over the whole period under study the average German worker had an income advantage of about 10 percent to 11 percent compared to the average Portuguese worker. The decomposition shows that most of this income advantage of Germans can be attributed to their endowment with skills. In 1975, for example, 98 percent of the wage differential was due to differences in observable skills. 
TABLE 6

Wage Differentuals BetWeen PORTUGUESE Migrants AND GeRmans

\begin{tabular}{|c|c|c|c|c|c|c|}
\hline & \multicolumn{3}{|c|}{1975} & \multicolumn{3}{|c|}{1982} \\
\hline & Total & Unexplained & Explained & Total & Unexplained & Explained \\
\hline Total & -0.112 & -0.001 & -0.110 & -0.096 & 0.003 & -0.099 \\
\hline Low school, no voc. training & 0.001 & 0.012 & -0.010 & 0.041 & 0.023 & 0.018 \\
\hline Vocational training & -0.091 & -0.041 & -0.050 & -0.090 & -0.050 & -0.040 \\
\hline Age $<35$ & -0.032 & 0.039 & -0.071 & -0.028 & 0.096 & -0.123 \\
\hline Age $35-49$ & -0.162 & -0.027 & -0.135 & -0.175 & -0.029 & -0.147 \\
\hline Age $>50$ & -0.307 & -0.191 & -0.116 & -0.141 & -0.010 & -0.131 \\
\hline Blue collar 1 & 0.019 & 0.004 & 0.015 & 0.073 & 0.026 & 0.046 \\
\hline Textile & -0.112 & -0.009 & -0.103 & -0.125 & -0.006 & -0.120 \\
\hline Iron & -0.120 & -0.007 & -0.113 & -0.123 & -0.030 & -0.093 \\
\hline Mechanical engineering & -0.071 & 0.011 & -0.082 & -0.077 & 0.025 & -0.103 \\
\hline \multirow[t]{3}{*}{ Chemistry } & -0.168 & -0.013 & -0.154 & -0.118 & 0.013 & -0.131 \\
\hline & \multicolumn{3}{|c|}{1986} & \multicolumn{3}{|c|}{1990} \\
\hline & Total & Unexplained & Explained & Total & Unexplained & Explained \\
\hline Total & -0.101 & 0.019 & -0.120 & -0.109 & 0.039 & -0.148 \\
\hline Low school, no voc. training & 0.054 & 0.039 & 0.015 & 0.048 & 0.045 & 0.003 \\
\hline Vocational training & -0.102 & -0.027 & -0.075 & -0.075 & 0.027 & -0.102 \\
\hline Age $<35$ & -0.006 & 0.144 & -0.150 & -0.085 & 0.071 & -0.156 \\
\hline Age $35-49$ & -0.169 & -0.024 & -0.145 & -0.100 & 0.043 & -0.143 \\
\hline Age $>50$ & -0.200 & -0.093 & -0.107 & -0.146 & -0.020 & -0.126 \\
\hline Blue collar 1 & 0.065 & 0.033 & 0.032 & 0.055 & 0.039 & 0.016 \\
\hline Textile & -0.003 & 0.130 & -0.133 & -0.016 & 0.064 & -0.080 \\
\hline Iron & -0.053 & 0.085 & -0.138 & -0.070 & 0.087 & -0.157 \\
\hline Mechanical engineering & -0.121 & 0.005 & -0.126 & -0.039 & 0.084 & -0.123 \\
\hline Chemistry & -0.085 & 0.016 & -0.102 & -0.069 & 0.048 & -0.166 \\
\hline
\end{tabular}

Notes: D: Germans, PGE; Portuguese in Germany, P: Portuguese in Portugal; all numbers are expressed as percentage of the German wage ( $\left.w_{0}\right)$.

Interpreting the unexplained part of the wage differential as an indicator for unobserved abilities, these results suggest that Portuguese guestworkers are positively self-selected with respect to unobserved characteristics compared to the average German worker. It might be that the unexplained wage differential could be partly caused by differences in hours worked for which we are unable to control. However, working hours themselves are not a characteristic of a person and could be interpreted as a proxy for unobservable characteristics like motivation.

Table 6 further reveals remarkable differences in the wage differential and the decomposition across different groups. First, Portuguese with low educational attainment and low-skilled blue-collar workers, who account for the majority of Portuguese migrants, exhibit an earnings advantage compared to the average German in the same group. For both groups, the Portuguese have an advantage in their skill levels and in their unobserved characteristics. Since it can be assumed that most of these individuals migrated to Germany during the recruitment period, these results highlight the success of the German recruitment system. Germany was not only able to select the migrants 
according to the needs of the German labor market, it also attracted highly motivated workers. Second, Table 6 suggests that for those Portuguese groups with an advantage (disadvantage) in the remuneration of their skills, this advantage (disadvantage) tends to increase (decrease) over time. This result suggests that mainly those migrants with lower levels of unobserved skills left Germany.

\section{CONCLUSIONS}

Using a large data set for the period 1975-1990 provided by the German Labor Office, we were able to analyze the labor market performance of such a small group of immigrants as the Portuguese workers in Germany. We were further able to match German data with Portuguese cross-section data for 1982 and 1986, allowing the analysis of the selection process of guestworkers in terms of observed and unobserved characteristics. The innovation of our contribution is the combination of data sets from the sending and receiving countries, which enables us to analyze more deeply the selection mechanism.

Descriptive comparisons have revealed that Portuguese guestworkers have lower levels of education than Germans and those workers who stayed in Portugal. However, compared to Portuguese workers who stayed at home, a higher percentage of migrants have had vocational training. The sectoral distribution of Portuguese migrants is more similar to that of Germans than to those of workers in Portugal, and it assimilates further over time.

Estimation of earnings equations using both data sets have shown that Portuguese workers who stayed in Portugal would have received higher wages if they had migrated to Germany than those who actually did, whereas those who migrated to Germany would have earned less in Portugal than their Portuguese counterparts. These results suggest that Portuguese migrants are negatively self-selected with regard to observed characteristics if compared to those who stayed at home.

However, for the majority of Portuguese workers in Germany, namely low-skilled blue-collar workers, a positive self-selection has been revealed. A comparison of the wages of German natives and Portuguese guestworkers using an Oaxaca decomposition suggests that the remuneration is higher for the latter. This implies that Portuguese guestworkers in Germany are positively self-selected in terms of unobserved skills if compared to the same German subgroup in the labor force. These results indicate that in the period of active recruitment of guestworkers in the late 1950s and the 1960s, Germany was not only able to attract migrants with the types of skills demanded in the 
labor market, but also migrants with relatively good unobserved characteristics such as motivation.

\section{REFERENCES}

Baganha, $M$.

1994 “As Correntes Emigratorias Portuguesas no Seculo XX," Análise Social, 31:959-980.

1993 "Principais Características e Tendências da Emigração Portuguesa." In Estruturas Sociais e Desenvolvimento. Ed. Aps. Lisboa: Fragmentos, Vol. 1:819-835.

1991 "Portuguese Migration: Current Characteristics and Trends." Paper presented at Cost Workshop "Migration: Europe's Integration and the Labour Force," Louvain.

Bauer, T. and K. F. Zimmermann

1998 "Looking South and East: Labor Market Implications of Migration in Europe and Developing Countries." In Globalization of Labor Markets, Challenges, Adjustment and Policy Response in the European Union and the Less Developed Countries. Ed. O. Memedovic, A. Kuyvenhoven and W. T. M. Molle. Dordrecht: Kluwer Academic Publishers. Pp. 75-103.

1997 "Integrating the East: The Labor Market Effects of Immigration." In Europe's Economy Looks East: Implications for Germany and the EU. Ed. S. Black. Cambridge: Cambridge University Press. Pp. 269-306.

1996 "Gastarbeiter und Wirtschaftsentwicklung im Nachkriegsdeutschland," Jahrbuch fiir Wirtschaftsgeschichte, 96(2):73-108.

Bender, S., A. Haas, C. Klose

2000 "IAB Employment Subsample 1975-1995. Opportunities for Analysis Provided by the Anonymised Subsample." IZA Discussion Paper No. 117. Bonn: IZA.

Bender, S., J. Hilzendegen, G. Rohwer and H. Rudolph

1996 “Die IAB-Beschäftigtenstichprobe 1975-1990," Beiträge zur Arbeitsmarkt-und Berufsforschung, 197. Nürnberg: Institut für Arbeitsmarkt und Berufsforschung.

Borjas, G. J.

1994 "The Economics of Immigration," Journal of Economic Literature, 32:1667-1717.

1987 "Self-Selection and the Earnings of Immigrants," American Economic Review, 77:531-553.

Bundesanstalt für Arbeit

Various Years Amtliche Nachrichten der Bundesanstalt für Arbeit. Nürnberg: Bundesanstalt für Arbeit.

Greene, W. H.

1997 Econometric Analysis. New York: Macmillan. 
Mincer, J.

1974 Schooling, Experience and Earnings. New York: Columbia University Press.

Murteira, M.

1965 "Emigração e Política de Emprego em Portugal," Análise Social, 3(11):258-278.

Oaxaca, R. L.

1974 "Male-Female Wage Differentials in Urban Labor Markets," International Economic Review, 14:693-709.

Pereira, P. T.

1994 “Portuguese Emigration 1958-1985: Some Empirical Evidence," Empirical Economics, $19(4), 647-657$.

Ribeiro, F. G. C.

1986 Emigraçäo Portuguesa - Aspectos Relevantes Relativos às Politicas Adoptadas no Domínio da Emigração, desde a Última Guerra Mundial. Contribuição para o seu Estudo. Lisboa: Secretaria de Estado das Comunidades Portuguesas.

Schmidt, C., A. Stilz and K. F. Zimmermann

1994 "Mass Migration, Unions, and Government Intervention," Journal of Public Economics, 55:185-201.

Serra, E.

1975 "O Operario Emigrante Portugues na Sociedade Industrial Capitalista," Análise Social, $11: 67-102$.

Statistisches Bundesamt

Various Years, Statistisches, Jahrbuch. Stuttgart: Metzler und Poeschel.

Veall, M. R. and K. F. Zimmermann

1996 "Pseudo-R ${ }^{2}$ Measures for Some Limited Dependent Variable Models," Journal of Economic Surveys, 10:241-259.

1994 "Goodness of Fit Measures in the Tobit Model," Oxford Bulletin of Economics and Statistics, 56:485-499.

Vieira, J. C.

1999 "The Evolution of the Wage Structure in Portugal 1982-1992," Tinbergen Institute Research Series, University of Amsterdam.

Zimmermann, K. F.

1995a "Tackling the European Migration Problem," Journal of Economic Perspectives, 9:45-62.

1995b "European Migration: Push and Pull." In Proceedings of the World Bank Annual Conference on Development Economics 1994, Supplement to the World Bank Economic Review and the World Bank Research Observer 1995. Pp. 313-342. 